\title{
Analisis Faktor Syariah terhadap Kinerja Portofolio pada Pelemahan dan Penguatan Nilai Tukar Rupiah
}

\section{Analysis of Sharia Factors on Portfolio Performance in the Weakening and Strengthening of Rupiah Exchange Rates}

\author{
Edryoko Dwi Hardono* \\ Program Studi Magister Manajemen, Fakultas Ekonomi dan Manajemen, IPB University, Dramaga, Bogor 16680 \\ e-mail: edryoko@gmail.com \\ Budi Purwanto \\ Program Studi Magister Manajemen, Fakultas Ekonomi dan Manajemen, IPB University, Dramaga, Bogor 16680 \\ e-mail: budipurwanto@apps.ipb.ac.id \\ Wita Juwita Ermawat \\ Departemen Manajemen, Fakultas Ekonomi dan Manajemen, IPB University, Dramaga, Bogor 16680 \\ e-mail:witaman@apps.ipb.ac.id
}

\begin{abstract}
IHSG and ISSI in the last three periods show that standard deviations have increased and the yield rate has declined. Preliminary observations found that during this period there was a weakening of the Rupiah against the US dollar which was reported to weaken from February to October 2018 and regained strength afterwards. The focus of this research is to analyze the performance of Islamic stock portfolios and general stock portfolios compiled with the Markowitz method under conditions of a weakening exchange rate and when the exchange rate conditions strengthen. The results of the portfolio formation reveal that, more Islamic stocks are needed when the condition of the rupiah exchange rate weakens and fewer Islamic stocks are needed when the exchange rate conditions strengthen. Islamic stock portfolios have returns and risks that are greater than the general portfolio in each condition. However, the performance of the Islamic stock portfolio is inversely proportional to the general stock portfolio.
\end{abstract}

Keyword: Investor, Performance, Return, Risk, Sharia, Standard Deviation

\begin{abstract}
ABSTRAK
IHSG dan ISSI dalam tiga periode terakhir menunjukan standar deviasi yang meningkat dan tingkat imbal hasil yang menurun. Pengamatan awal menemukan bahwa pada periode tersebut terdapat pelemahan nilai tukar Rupiah terhadap dolar AS yang dilaporkan melemah dari Februari hingga Oktober 2018 dan kembali menguat setelahnya. Fokus pada penelitian ini adalah menganalisis kinerja portofolio saham syariah dan portofolio saham umum yang disusun dengan metode Markowitz pada kondisi nilai tukar melemah dan ketika kondisi nilai tukar menguat. Hasil pembentukan portofolio mengungkapkan bahwa, saham syariah lebih banyak dibutuhkan ketika kondisi nilai tukar rupiah melemah dan dibutuhkan saham syariah yang lebih sedikit pada saat kondisi nilai tukar menguat. Portofolio saham syariah memiliki return dan risiko yang lebih besar daripada portofolio umum pada setiap kondisi. Akan tetapi kinerja dari portofolio saham syariah tersebut berbanding terbalik dengan portofolio saham umum.
\end{abstract}

Kata Kunci: Investor, Kinerja, Return, Risiko, Syariah, Standard Deviasi 


\section{PENDAHULUAN}

Investasi saham syariah merupakan salah satu alternatif investasi yang harus diperhitungkan dalam dunia pasar modal saat ini oleh investor. Perkembangan indeks saham syariah yang cukup baik menjadi alasan untuk hal tersebut. Melihat dari sisi sejarahnya, negara yang pertama kali menginisiasi terbentuknya indeks syariah dan equity fund seperti reksadana adalah Amerika Serikat. Hal ini ditandai dengan peluncuran The North American Islamic Trust sebagai equity fund pertama di dunia pada tahun 1986 oleh The Amana Fund. Selanjutnya pada bulan Februari 1999, Dow Jones meluncurkan indeks pasar syariah yang pertama, yaitu Dow Jones Islamic Market Index (DJIMI) merupakan bagian dari kelompok indeks-indeks global Dow Jones (Dow Jones Global Index atau DJGI).

Dow Jones Islamic Market Index ini meliputi saham-saham dari berbagai negara yang dikelompokkan berdasarkan negara asalnya maupun regionalnya. Adapun beberapa Dow Jones Islamic Market Index yang dimaksud adalah Dow Jones Islamic Market Index Europe, Dow Jones Islamic Market Index Asean, Dow Jones Islamic Market Index US dan Dow Jones Islamic Market Index Japan. Banyaknya saham-saham syariah dari berbagai negara yang masuk ke dalam Dow Jones Islamic Market Index ini telah membuktikan bahwa konsep ekonomi syariah adalah konsep yang berlaku universal dan dapat diterima oleh berbagai kalangan di berbagai negara.

Munculnya investasi saham syariah di dunia pasar modal sebenarnya dilatar belakangi oleh keinginan untuk mengakomodir kebutuhan umat Islam yang ingin melakukan investasi saham dengan prinsip syariah. Apabila dilihat dari latar belakang tersebut, maka Indonesia memiliki potensi yang baik untuk mengembangkan investasi saham syariah. Namun, bukti empiris yang ditemukan oleh Pepinsky (2012) menyatakan bahwa optimisme mengenai perkembangan, perubahan sosial dan keuangan Islam kontemporer di Indonesia tidak membenarkan bahwa doktrin "kemusliman" merupakan satu-satunya indikator dalam pemilihan instrumen keuangan syariah. Hal ini menandakan bahwa instrumen keuangan syariah di Indonesia tidak hanya dicari oleh umat Islam tetapi juga oleh individu investor secara global. Sementara Gait dan Worthington (2008) dari hasil penelitiannya menunjukkan bahwa muslim yang mematuhi moral bounded syariah adalah pengguna utama instrumen keuangan syariah. Berdasarkan dari kedua hasil penelitian tersebut mengungkapkan bahwa dalam berinvestasi saham tidak ada investor yang anti terhadap kesyariahan tetapi ada investor yang anti terhadap ketidaksyariahan, yakni investor muslim.

Pada praktiknya tidak semua saham dapat dikategorikan sebagai saham syariah, karena emiten sebagai penerbit saham terlebih dahulu harus patuh terhadap peraturan kesyariahan yang berlaku. Derigs dan Marzban (2009) memaparkan bahwa ada penggambaran urutan kepatuhan yang harus dipenuhi dalam menjalankan investasi jika ingin dikategorikan sebagai investasi syariah. Kepatuhan yang dimaksud dituangkan dalam sebuah peraturan yang mengandung lima prinsip syariah, yakni pelarangan bunga (riba), pelarangan ketidakpastian berlebihan (gharar), larangan spekulasi (maysir) risiko dan pembagian kembali dan larangan berinvestasi di industri yang 'tidak etis' (haram) (Shanmugam \& Zahari, 2009).

Indonesia, melalui peraturan OJK Nomor 35/POJK.04/2017 akan memilah emiten mana yang layak untuk dapat dikategorikan sebagai emiten syariah di Bursa Efek Indonesia dan terdaftar dalam Indeks Saham Syariah Indonesia (ISSI). Adanya prisip-prinsip syariah yang wajib dipatuhi oleh para emiten syariah dalam peraturan tersebut selain dapat dikatakan sebagai pembeda antara emiten syariah dan emiten non-syariah, dapat pula dikatakan sebagai pembatas kegiatan bisnis atau usaha yang dilakukan oleh para emiten syariah. Meskipun terdapat pembatasan terhadap ruang bisnisnya, ternyata minat untuk dapat menjadi emiten syariah di Bursa Efek Indonesia masih sangat besar.

Bursa Efek Indonesia secara konsisten mencatat tingginya nilai kapitalisasi saham syariah jika dibandingkan dengan nilai kapitalisasi saham non-syariah pada tiga tahun terakhir. Adapun nilai kapitalisasi saham syariah yang ditunjukkan pada Indeks Saham Syariah Indonesia (ISSI) terhadap total kapitalisasi saham di Bursa Efek Indonesia adalah 55,10 persen di tahun 2010, 52,5 persen di tahun 2017 dan 52,2 persen di tahun 2018. Tingginya nilai kapitalisasi ini tidak 
hanya semata-mata dipengaruhi oleh banyaknya jumlah saham syariah yang beredar tetapi juga dipengaruhi oleh harga saham itu sendiri, dimana semakin tinggi permintaan investor terhadap saham maka semakin tinggi pula harga saham tersebut. Hal ini menunjukkan ketertarikan investor di Indonesia terhadap investasi saham syariah.

Adanya perbedaan investor dalam mempertimbangkan aspek kesyariahan ketika melakukan investasi saham di Bursa Efek Indonesia, maka ISSI dapat dikatakan sebagai indeks alternatif investasi saham bagi investor yang mempertimbangkan prinsip syariah dalam kegiatan berinvestasi, dimana kemudian indeks tersebut menjadi sumber pemilihan saham potensial dalam membentuk portofolio syariah. Sementara IHSG dapat dikatakan sebagai indeks alternatif investasi saham bagi investor yang tidak mempertimbangkan prinsip kesyariahan yang harus dipatuhi dalam kegiatan berinvestasi dimana kemudian indeks tersebut menjadi sumber pemilihan saham potensial dalam membentuk portofolio yang disebut dengan portofolio umum.

Berdasarkan data dari Bank Indonesia, dinamika nilai tukar Rupiah pada 2018 tergambar dari kondisi permintaan neto di pasar valas domestik. Pada saat itu volatilitas Rupiah meningkat secara rerata menjadi 8,1 persen, dari semula 7,0 persen pada Januari 2018 yang pada kemudian meningkatkan permintaan neto valas dan memberikan tekanan terhadap Rupiah mulai Februari 2018 sampai dengan Oktober 2018. Pada periode tersebut Rupiah terdepresiasi 12,5 persen, dimana Rupiah sempat mencapai level Rp15.235 per dolar AS. Tekanan terhadap Rupiah menurun pada November - Desember 2018 seiring respons antisipatif kebijakan moneter dalam melakukan stabilisasi nilai tukar Rupiah. Respons kebijakan moneter yang pre-emptive, front loading dan ahead of the curve dapat meningkatkan daya tarik aset keuangan domestik dan meningkatkan aliran masuk modal asing. Aliran masuk modal asing juga dipengaruhi prospek perekonomian Indonesia yang tetap terjaga. Perkembangan ini pada gilirannya mendorong penguatan Rupiah yang pada November - Desember 2018. Adapun dinamika perubahan nilai tukar Rupiah terhadap dolar AS dapat dilihat pada Gambar 1.

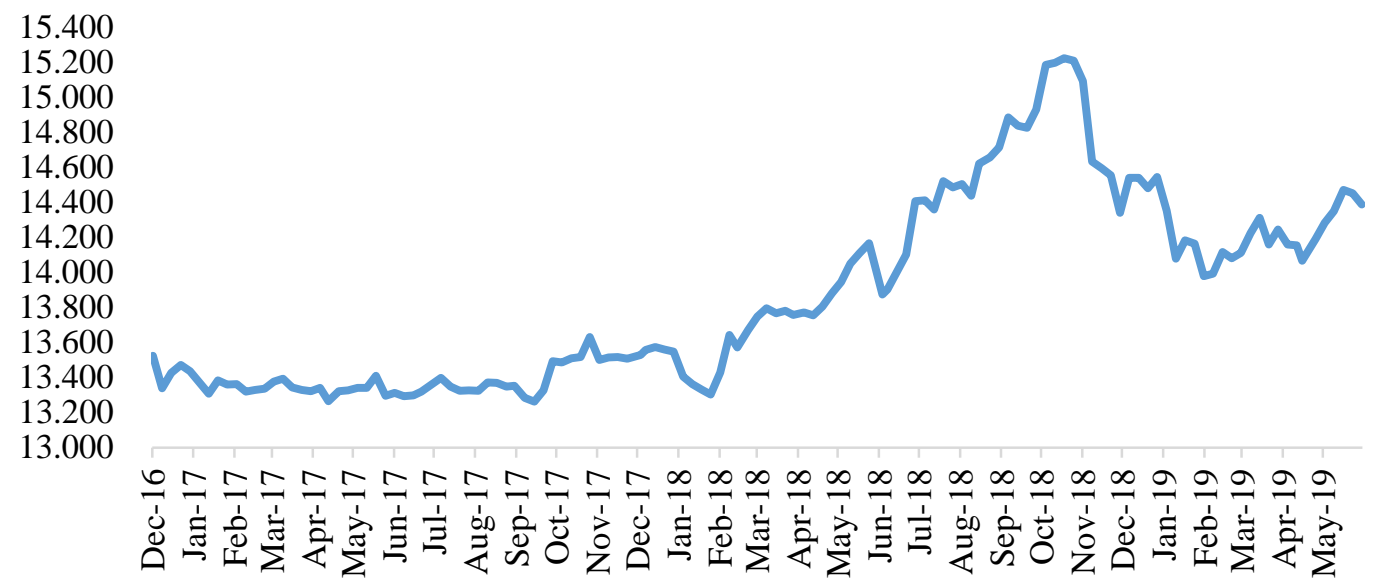

Gambar 1. Grafik perubahan nilai tukar

Menurut Ang (1997), pelemahan nilai tukar rupiah terhadap mata uang asing merupakan sinyal negatif bagi investor sehingga dapat mempengaruhi harga saham tersebut dan begitu pula sebaliknya. Lebih lanjut, sinyal negatif yang diterima oleh investor secara terus-menerus dapat mempengaruhi permintaan investor terhadap saham di pasar modal. Menurut Halim (2003), semakin tinggi permintaan investor terhadap saham maka semakin tinggi pula return saham tersebut dan begitu pula sebaliknya. Dampak melemahnya nilai tukar mata uang terhadap harga saham di pasar modal dapat terlihat dalam pergerakan indeks saham, dimana indeks saham islami dan non-islami dilaporkan responsif terhadap risiko ekonomi makro dan mikro ekonomi (Girrard \& Hassan, 2008; Albaity \& Ahmad, 2011).

Investasi saham sejatinya merupakan instrumen keuangan yang memiliki tingkat risiko yang tinggi dan ini berlaku untuk saham syariah maupun saham non-syariah. Dalam sebuah studi

Jurnal Manajemen dan Organisasi (JMO),

Vol. 11 No. 2, Agustus 2020 
yang dilakukan oleh Fabozzi (1999), salah satu usaha yang dapat investor lakukan untuk mengurangi kerugian/risiko investasi saham adalah dengan cara berbagai jenis saham dengan membentuk portofolio. Investasi portofolio dalam bentuk saham atau ekuitas umumnya sangat terpengaruh oleh risiko. Untuk itu, perlu dilakukan strategi diversifikasi dengan mengalokasikan dana pada berbagai aset (Markowitz, 1952). Alokasi aset merupakan penentu utama dari risiko dan keuntungan suatu portofolio (Brinson et al., 1986; Brinson et al., 1991; Ibbotson \& Kaplan, 2000; dan Davis et al., 2007). Investor berharap, risiko yang timbul dari expected return dapat dikurangi dengan melakukan portofolio (Miguel, Garlappi \& Uppal, 2009). Dengan demikian, semakin banyak saham yang dapat didiversifikasi maka risiko yang terdapat dalam portofolio dapat terdistribusi dengan baik.

Sharpe (1995) menyatakan bahwa risiko dan return merupakan dua ciri khas dari investasi, oleh karenanya sangat penting untuk mengetahui sumbernya. Pembentukan portofolio yang dilakukan oleh investor hanya akan mengurangi risiko yang tidak sistematis saja sehingga diperlukan analisis lebih lanjut pada portofolio yang telah di bentuk tersebut. Analisis yang dimaksud berupa pengukuran kinerja pada portofolio yang kemudian dibandingkan dengan kinerja dari portoflio lain sebagai benchmark.

Sesuai dengan sifat rasional investor yang memiliki kencenderungan risk averse atau menghindari risiko dalam berinvestasi maka penggunaan risiko total dalam pengukuran kinerja portofolio. Menurut Solnik (1995), risiko total dari portofolio tidak hanya bergantung pada jumlah saham yang terdapat dalam portofolio, tetapi juga pada risiko dari tiap-tiap saham individu dan tingkat dimana risiko itu independen. Risk-adjusted measurement merupakan teknik yang digunakan untuk mengukur kinerja portofolio saham. Indeks Sharpe dikembangkan oleh William F. Sharpe pada tahun 1966, dapat digunakan untuk mengukur kinerja suatu portofolio. Penggunaan Indeks Sharpe dianggap relavan karena dalam melakukan pengukurannya menggunakan risiko total sehingga lebih akurat memperhitungkan risiko portofolio.

Penelitian tentang perbandingan kinerja portofolio saham syariah dan saham non-syariah telah banyak dilakukan kajian ilmiah (riset) terdahulu terutama pada saat krisis atau pelemahan ekonomi. Alam dan Rajjaque (2010) melakukan penelitian tetang pengukuran kinerja saham syariah dan saham non-syariah pada indeks S\&P500, sedangkan Ho et al. (2014) melakukan penelitian pada beberapa indeks saham di dunia. Secara khusus Mubarok et al. (2017). Sementara, Chiadmi dan Ghaiti (2012) melakukan perbadingan return dan risk antara saham syariah dengan saham non-syariah pada indeks S\&P 500. Sedangkan Chen dan Lim (2015) melakukan penelitian yang dilakukan untuk mengetahui seberapa banyak saham syariah diperlukan dalam suatu portofolio kombinasi.

Berbagai penelitian telah mencoba untuk menganalisis perbedaan antara saham syariah dan saham non-syariah, serta mengukur kinerja portofolio saham yang dibentuk dari saham syariah dan saham non-syariah. Penelitian ini juga dimaksudkan untuk memeriksa dan menganalisis perbedaan saham syariah dan saham non-syariah serta kinerja dari portofolio saham tersebut, namun pada saat pelemahan maupun pada saat penguatan nilai tukar Rupiah terhadap dolar AS. Karena dalam berinvestasi saham tidak ada investor yang anti terhadap kesyariahan tetapi ada investor yang anti terhadap ketidaksyariahan, maka dalam mengukur kinerja portofolio saham, penelitian ini akan terlebih dahulu membentuk dua jenis portofolio, yakni portofolio syariah yang disusun dari saham potensial yang terdafrtar dalam ISSI dan portofolio umum yang disusun dengan tidak mempertimbangkan prinsip syariah, dimana saham potensial yang membentuk portofolio tersebut bersumber dari IHSG.

\section{METODOLOGI PENELITIAN}

Penelitian ini menggunakan data sekunder dan metode yang digunakan dalam

Jurnal Manajemen dan Organisasi (JMO),

Vol. 11 No. 2, Agustus 2020 Hal. 103-114 pengumpulan data adalah metode dokumentasi serta metode studi pustaka, dimana referensi data yang diperoleh dari berbagai jurnal ilmiah. Data berupa informasi saham akan diambil di web resmi Bursa Efek Indonesia www.idx.co.id. Adapun data saham yang akan digunakan dalam 
penelitian ini adalah data return saham mingguan pada tanggal 1 Desember 2017 sampai dengan 31 Mei 2019.

Pemilihan sampel dalam penelitian ini mengunakan metode purposive sampling dengan kriteria sebagai berikut :

1. Saham perusahaan terdaftar di Bursa Efek Indonesia dari bulan Desember 2016 sampai dengan Mei 2019. Rentang waktu tersebut dijadikan kriteria karena selama periode tersebut saham syariah mengalami tren peningkatan jumlah emiten yang konsisten dengan jumlah yang lebih besar dari periode-periode sebelumnya.

2. Saham syariah, adalah saham yang diterbitkan oleh emiten yang konsisten terdaftar dalam ISSI selama 5 periode terakhir sebagaimana pengumuman hasil klasisfikasi emiten syariah diterbitkan oleh OJK di setiap awal periodenya. Adapun 5 periode yang dimaksud adalah periode Desember 2016 - Mei 2017, Juni 2017 - November 2017, Desember 2017 - Mei 2018, Juni 2018 - November 2018 dan Desember 2018 - Mei 2019. Rentang waktu pemilihan sampel saham syariah ini karena sudah cukup membuktikan kesyariahan para emitenya untuk terus patuh terhadap prinsip atau peraturan syariah yang berlaku. Saham yang tidak konsisten terdaftar dalam ISSI tetapi konsisten terdaftar di Bursa Efek Indonesia akan dikategorikan saham non-syariah salam penelitian ini.

Penyusunan portofolio dalam penelitian akan menggunakan metode Markowitz dengan mempertimbangkan kondisi pada saat nilai tukar Rupiah terhadap dolar AS mengalami pelemahan dan penguatan, dimana return saham yang digunakan adalah nilai return pada saat kondisi tersebut terjadi. Portofolio yang disusun dalam penelitian ini akan diukur dengan metode sharpe ratio sesuai dengan karakteristik rasional para inevestor yang risk averse, sehingga saham yang memiliki nilai return negatif tidak dimasukan ke dalam objek penelitian ini. Kerangka pemikiran penelitian dalam penelitian ini dapat dilihat pada Gambar 2.

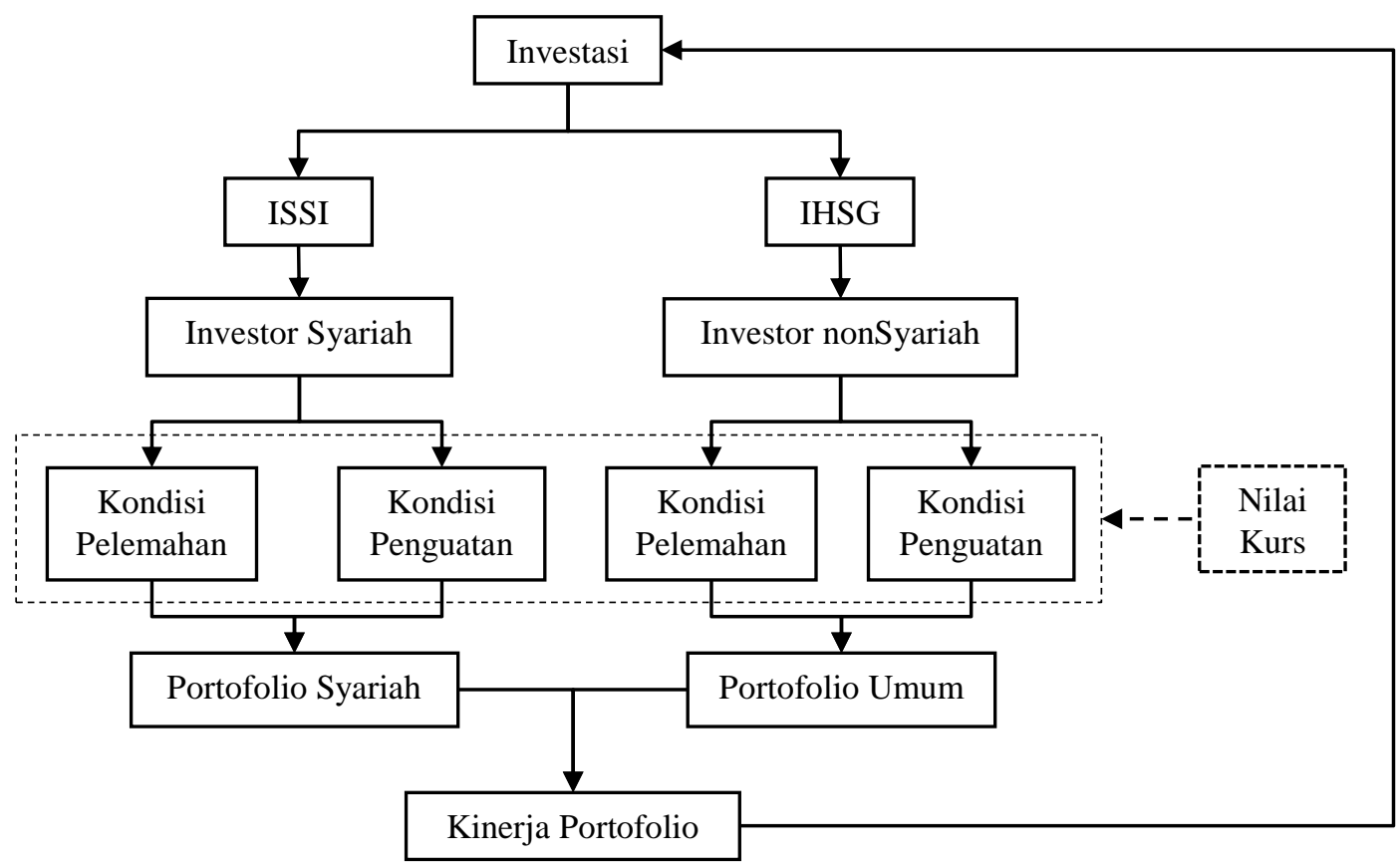

Gambar 2. Kerangka pemikiran

Penelitian ini melakukan pengolahan data kuantitatif yang dibantu dengan program komputer, Microsoft Office Excel 2010 untuk menyusun portofolio dan menghitung kinerja dari portofolio yang telah tersusun tersebut. Berikut langkah-langkah dan rumus yang digunakan dalam menyusun portofolio model Markowitz:

1. Menghitung imbal hasil dengan persamaan sebagai berikut (Hartono, 2010) 


$$
R_{i t}=\frac{\left(P_{i t}-P_{i t-1}\right)+D_{1}}{P_{i t-1}}
$$

Keterangan :

Rit = Return pada waktu yang diharapkan

$\mathrm{P}_{\mathrm{t}-1} \quad=$ Harga saham pada awal periode

$\mathrm{Pt} \quad=$ Harga saham pada akhir periode

$\mathrm{D}_{1} \quad=$ Deviden yang dibagikan

2. Menghitung nilai yang diharapkan (expected return) menurut Bodie et al. (2006). persamaan expected return atau rata-rata tertimbang yang berasal dari return (tingkat imbal hasil) pada setiap pengamatan. Jika data merupakan data historis dengan $n$ pengamatan, maka probabilitas untuk setiap pengamatan sebesar $\mathrm{n}^{-1}$. Nilai expected return yang dimaksud dihitung dengan rumus berikut:

$$
E\left(R_{i}\right)=\sum_{t}^{n}=1 p_{i t} R_{i t}=\frac{\sum_{t=1}^{n} R_{i t}}{n}
$$

Keterangan:

$\mathrm{E}\left(\mathrm{R}_{\mathrm{i}}\right) \quad=$ Expected return saham (i)

$\mathrm{R}_{\text {it }} \quad=$ Return saham (i) pada waktu yang diharapkan ( $\mathrm{t}$ )

$\mathrm{N} \quad=$ Jumlah data untuk saham (i) yang mungkin terjadi

$\mathrm{t}=$ Periode (waktu yang diharapkan)

3. Menghitung risiko (varian dan standard deviasi) investasi tiap saham. Ukuran penyebaran ini dimaksudkan untuk mengetahui seberapa jauh kemungkinan nilai yang akan diperoleh, menyimpang dari nilai yang diharapkan. Menurut Husnan (2003), perhitungan dapat dilakukan dengan persamaan berikut:

$$
\begin{gathered}
\sigma_{i}^{2}=\frac{\sum_{j=1}^{n}\left[\left(R_{i j}-E\left(R_{i}\right)\right)\right]^{2}}{n} \\
\operatorname{dan} \\
\sigma_{1}=\sqrt{\sigma_{1}^{2}}
\end{gathered}
$$

Keterangan:

$\sigma_{i}^{2} \quad=$ Varian

$\sigma_{i} \quad=$ Standard Deviasi

$E\left(R_{i}\right) \quad=$ Expected return saham (i)

$R_{i j} \quad=$ Return saham (i) yang telah diperoleh

$\mathrm{n} \quad=$ Jumlah sebaran data untuk saham (i) yang mungkin terjadi

$\mathrm{j} \quad=$ Periode saham yang dimiliki

4. Menghitung kovarian antara dua saham dalam portofolio. Kovarian adalah ukuran statistik dari hubungan antara dua variabel acak (Bodie et al., 2006). Nilai kovarian yang positif mengindikasikan imbal hasil sekuritas cenderung bergerak ke arah yang sama. Sedangkan kovarian yang negatif mengindikasikan kecenderungan imbal hasil bergerak berlawanan. Menurut Hartono (2010), kovarian dihitung dengan persamaan sebagai berikut: 


$$
\sigma^{i j}=\sum_{i=t}^{n} \frac{\left[\left(R_{i t}-E\left(R_{i}\right)\right) \cdot\left(R_{j t}-E\left(R_{j}\right)\right)\right]}{n}
$$

Keterangan:

$\sigma^{i j} \quad=$ Koefisien korelasi return saham $\mathrm{i}$ dan $\mathrm{j}$

$R_{i t} \quad=$ Return saham (i) pada waktu yang diharapkan ( $\left.\mathrm{t}\right)$

$E\left(R_{i}\right) \quad=$ Expected return saham (i)

$R_{j t} \quad=$ Return saham (j) pada waktu yang diharapkan $(\mathrm{t})$

$E\left(R_{j}\right) \quad=$ Expected return saham (i)

$\mathrm{n} \quad=$ Jumlah data observasi

i $\quad=$ Indeks (i)

5. Menghitung koefisien korelasi nilai antar saham. Besar kecilnya koefisien korelasi akan berpengaruh terhadap risiko portofolio. Rumus yang digunakan untuk menghitung korelasi menurut Husnan dan Pudjiastuti (2006) adalah sebagai berikut:

$$
\rho=\frac{n \sum X Y-\sum X \sum Y}{\sqrt{\left\{\left[n \sum X^{2}-\left(\sum X\right)^{2}\right]\left[n \sum Y^{2}-\left(\sum Y\right)^{2}\right]\right\}}}
$$

Keterangan:

$\square \quad=$ Koefisien korelasi

$\mathrm{n}=$ Jumlah observasi

$\mathrm{X} \quad=$ Tingkat expected return dari saham $\mathrm{X}$

$\mathrm{Y} \quad=$ Tingkat expected return dari saham $\mathrm{Y}$

6. Menghitung imbal hasil yang diharapkan (expected return) portofolio dengan persamaan sebagai berikut (Husnan, 2003):

$$
E\left(R_{p}\right)=\sum_{i=1}^{n} X_{i} E\left(R_{i}\right)
$$

Keterangan:

$\mathrm{E}\left(R_{p}\right)=$ Expected return seluruh investasi

$\mathrm{Xi}=$ Proporsi investasi pada indeks $\mathrm{i}$

$\mathrm{E}\left(R_{i}\right) \quad=$ Expected return saham

$\mathrm{n} \quad=$ Jumlah sebaran data saham yang mungkin terjadi

$\mathrm{i} \quad=$ indeks

7. Menghitung risiko (varian dan standard deviasi) portofolio dengan persamaan sebagai berikut (Husnan, 2005):

$$
\begin{gathered}
\sigma_{p}^{2}=x_{1}^{2} \sigma_{1}^{2}+x_{2}^{2} \sigma_{i}^{2}+2\left(X_{1} X_{2} \rho_{12} \sigma_{1} \sigma_{2}\right) \\
\text { dan } \\
\sigma_{p}=\sqrt{\sigma_{p}^{2}}
\end{gathered}
$$

Jurnal Manajemen dan Organisasi (JMO),

Vol. 11 No. 2

Agustus 2020 Hal. 103-114 
Keterangan:

$\sigma_{p} \quad=$ Standard deviasi portofolio

$\sigma_{p}^{2} \quad=$ Varian portofolio

$\sigma_{i}^{2} \quad=$ Varian saham 1

$\sigma_{2}^{2} \quad=$ Varian saham 2

$\sigma_{12}=$ Koefisien korelasi antara retrun saham 1 dan saham 2

$X_{1} \quad=$ Proporsi investasi pada saham 1

$X_{2} \quad=$ Proporsi investasi pada saham 2

Kemudian untuk menghitung kinerja dari portofolio yang telah tersusun tersebut menggunakan Sharpe ratio dengan sudut pandang investor domestik Indonesia di Bursa Efek Indonesia dengan menggunakan BI rate sebagai acuan risk-free rate. Adapun rumus pengukuran kinerja Sharpe ratio tersebut adalah sebagai berikut:

$$
\text { Sharpe ratio }=\frac{\text { Average portfolio return-Average risk-free rate of return }}{\text { Standardd deviation of portfolio returns }}
$$

\section{HASIL DAN PEMBAHASAN}

\section{Gambaran Umum Objek Penelitian}

Objek penelitian ini adalah seluruh emiten yang terdaftar dalam Bursa Efek Indonesia dari bulan Desember 2016 sampai dengan Mei 2019. Emiten yang tedaftar dalam kurun waktu tersebut terdapat 526 yang terdiri dari 279 emiten syariah dan 247 emiten non-syariah. Emiten syariah tersebut adalah emiten yang konsisten terdaftar dalam ISSI selama lima periode terakhir, sebagaimana dengan periode pada kriteria emiten syariah yang disyaratkan dalam penelitian ini. Penyusunan portofolio dengan metode Markowitz akan menggunakan pendekatan mean variance yang memerlukan syarat return pada masing-masing saham harus berdistribusi normal (Wahyuni, 2013). Hasil dari uji normalitas tersebut mendapati 68 saham memiliki return yang berdistribusi secara normal dalam periode penelitian ini, yakni Desember 2017 sampai dengan Mei 2019. Saham tersebut kemudian menjadi objek dalam penyusunan portofolio dengan metode Markowitz.

\section{Penyusunan Portofolio Saat Kondisi Pelemahan Nilai Tukar Rupiah}

Pertama, penyusunan portofolio syariah pada saat terjadinya pelemahan nilai tukar terhadap dolar AS. Hasil dari penyusunan tersebut dapat terlihat pada Tabel 1, dimana terdapat 9 saham potensial ke dalam portofolio syariah tersebut. Pada portofolio syariah tersebut bobot optimal terbesar terdapat pada saham dengan kode emiten CPIN yang memiliki nilai bobot optimal 32,76 persen, sementara bobot optimal terendah sebesar 0,27 persen terdapat pada saham dengan kode emiten RALS.

Tabel 1. Bobot optimal portofolio syariah saat rupiah melemah

\begin{tabular}{lr}
\hline Kode & $\begin{array}{r}\text { Bobot optimal } \\
(\%)\end{array}$ \\
\hline APLI & 1,68 \\
CPIN & 32,76 \\
ERAA & 25,64 \\
INDS & 12,89 \\
ITMG & 3,46 \\
PYFA & 2,30 \\
RALS & 0,27 \\
RANC & 11,93 \\
RICY & 9,07 \\
\hline
\end{tabular}


Kedua, penyusunan portofolio umum pada saat terjadinya pelemahan nilai tukar terhadap dolar AS, dimana hasilnya mendapati 12 saham potensial didalamnya seerti yang tampak pada Tabel 2. Pada portofolio umum tersebut bobot optimal terbesar terdapat pada saham dengan kode emiten CPIN yang memiliki nilai bobot optimal 23,88 persen, sementara bobot optimal terendah sebesar 0,17 persen terdapat pada saham dengan kode emiten PNBN.

Tabel 2. Bobot Opimal portofolio umum saat rupiah melemah

\begin{tabular}{lc}
\hline Kode & $\begin{array}{c}\text { Bobot optimal } \\
(\%)\end{array}$ \\
\hline AMRT & 3,72 \\
APLI & 2,12 \\
BMAS & 13,49 \\
CPIN & 23,88 \\
ERAA & 17,07 \\
INDS & 10,00 \\
INKP & 5,02 \\
ITMG & 5,15 \\
PNBN & 0,17 \\
PYFA & 2,43 \\
RANC & 5,15 \\
RICY & 11,81 \\
\hline
\end{tabular}

Hasil penyusuan portofolio umum tersebut jika diamati lebih lanjut maka akan terlihat kontribusi dari saham syariah di dalamnya. Meskipun jumlah saham dalam portofolio umum tersebut lebih banyak dari jumlah saham pada portofolio syariah, namun bobot optimal saham syariah masih lebih unggul daripada saham non-syariah. Adapun, saham syariah yang sebelumnya masuk ke dalam portofolio syariah memiliki bobot optimal dalam portofolio umum tersebut adalah 77,60 perssen. Jumlah tersebut masih telah mendominasi bobot optimal dalam portofolio umum, meskipun terjadi fluktuasi pada jumlah bobot optimal pada saham syariah tersebut.

\section{Penyusunan Portofolio Saat Kondisi Penguatan Nilai Tukar Rupiah}

Pertama, penyusunan portofolio syariah pada saat terjadinya penguatan nilai tukar terhadap dolar AS. Hasil dari penyusunan tersebut mendapati 11 saham potensial dalam portofolio tersebut sebagaimana tampak pada Tabel 3. Pada portofolio syariah tersebut bobot optimal terbesar terdapat pada saham dengan kode emiten BRPT yang memiliki nilai bobot optimal 26,66 persen, sementara bobot optimal terendah sebesar 0,15 persen terdapat pada saham dengan kode emiten LKPR.

Tabel 3. Bobot Opimal portofolio syariah saat rupiah menguat

\begin{tabular}{lr}
\hline Kode & $\begin{array}{r}\text { Bobot optimal } \\
(\%)\end{array}$ \\
\hline ACES & 9,93 \\
BMTR & 090 \\
BRPT & 26,66 \\
IGAR & 9,98 \\
INDS & 12,80 \\
LPCK & 3,98 \\
LPKR & 0,15 \\
PYFA & 7,31 \\
RALS & 13,06 \\
TPIA & 1,01 \\
WIKA & 14,21 \\
\hline
\end{tabular}

Kedua, penyusunan portofolio umum pada saat terjadinya pelemahan nilai tukar terhadap dolar AS, dimana hasilnya mendapati 18 saham potensial didalamnya seperti yang tampak pada Tabel 4. Pada portofolio umum tersebut bobot optimal terbesar terdapat pada saham dengan kode

Jurnal Manajemen dan Organisas JMO), Vol. 11 No. 2, Agustus 2020 Hal. $103-114$ 
emiten AMRT yang memiliki nilai bobot optimal 23,34 persen, sementara bobot optimal terendah sebesar 1,06 persen terdapat pada saham dengan kode emiten SMRA.

Tabel 4. Bobot Opimal portofolio umum saat rupiah menguat

\begin{tabular}{lr}
\hline \multicolumn{1}{c}{ Kode } & $\begin{array}{r}\text { Bobot optimal } \\
(\%)\end{array}$ \\
\hline ACES & 7,94 \\
AMRT & 23,34 \\
APLI & 2,17 \\
BMAS & 5,54 \\
BMTR & 3,10 \\
BRPT & 10,45 \\
INDS & 13,16 \\
LPCK & 2,33 \\
LPKR & 7,04 \\
PJAA & 2,04 \\
PWON & 2,96 \\
PYFA & 6,58 \\
RALS & 2,01 \\
SMRA & 1,06 \\
SSIA & 2,78 \\
TIFA & 3,07 \\
TPIA & 2,15 \\
WIKA & 2,28 \\
\hline
\end{tabular}

Hasil penyusuan portofolio umum pada saat nilai tukar rupiah mulai menguat tersebut, jika diamati lebih lanjut maka akan terlihat kontribusi dari saham syariah di dalamnya. Meskipun jumlah saham dalam portofolio umum tersebut lebih banyak dari jumlah saham pada portofolio syariah, namun bobot optimal saham syariah masih lebih unggul daripada saham non-syariah. Adapun, saham syariah yang sebelumnya masuk ke dalam portofolio syariah memiliki bobot optimal dalam portofolio umum tersebut adalah 57,03 persen. Jumlah tersebut masih telah mendominasi bobot optimal dalam portofolio umum, meskipun terjadi fluktuasi pada jumlah bobot optimal pada saham syariah tersebut.

\section{Return dan Risiko Portofolio}

Tabel 4, memperlihatkan tingkat imbal hasil yang diharapkan dan risiko yang ditunjukkan dengan standard deviasi pada portofolio yang telah terbentuk. Besar kecilnya tingkat imbal hasil yang diharapkan dan risko yang ditunjukkan dengan standard deviasi pada tiap portofolio mimiliki besaran yang berbeda. Secara umum tingkat imbal hasil yang diharapkan pada portofolio syariah lebih tinggi daripada portofolio umum untuk disetiap kondisi. Hal tersebut diikuti oleh risiko yang bergerak searah dengan tingkat imbal hasil yang diharapkannya, dimana risiko pada portofolio lebih tinggi daripada portofolio umum.

Tabel 5. Perbandingan return dan risk optimal portofolio syariah dan umum

\begin{tabular}{clcc}
\hline \multirow{2}{*}{ Kondisi } & Portofolio & $\begin{array}{c}\text { Tingkat Imbal } \\
\text { Hasil } \\
(\%)\end{array}$ & $\begin{array}{c}\text { Stadard Deviasi } \\
(\%)\end{array}$ \\
\hline \multirow{2}{*}{ Pelamahan Nilai Tukar } & Syariah & 1,46 & 3,55 \\
& Umum & 1,25 & 2,81 \\
\hline \multirow{2}{*}{ Penguatan Nilai Tukar } & Syariah & 1,13 & 1,66 \\
& Umum & 0,74 & 0,86 \\
\hline
\end{tabular}




\section{Pengukuran Kinerja Portofolio Optimal}

Portofolio optimal yang dibentuk pada tahap pelemahan dan penguatan nilai tukar rupiah terhadap USD memiliki perbedaan dari sisi tingkat imbal hasil yang diharapkan dan risikonya. Secara umum tingkat imbal hasil yang diharapkan pada prortofolio syariah lebih besar daripada tingkat imbal hasil yang diharapkan pada portofolio umum dan begitu pula risiko yang terkandung didalamnya.

Tabel 5. Hasil pengukuran kinerja portofolio syariah dan umum

\begin{tabular}{llc}
\hline Kondisi & Portofolio & Indeks Sharpe \\
\hline \multirow{2}{*}{ Pelamahan Nilai Tukar } & Syariah & 0,39 \\
& Umum & 0,41 \\
\hline \multirow{2}{*}{ Penguatan Nilai Tukar } & Syariah & 0,63 \\
& Umum & 0,76 \\
\hline
\end{tabular}

Pada Tabel 5 terlihat bahwa Sharpe ratio yang dihasilkan oleh portofolio umum lebih besar jika dibandingkan dengan portofolio syariah. Walaupun demikian, nilai Sharpe ratio dari kedua jenis portofolio tersebut memiliki nilai terbesar pada saat kondisi nilai tukar rupiah mengalami penguatan. Hasil tersebut memberikan bukti, bahwa ada kesamaan dalam pergerakkan kinerja pada kedua jenis portofolio tersebut. Selain itu, hasil dari pengukuran kinerja portofolio ini juga membuktikan bahwa besarnya tingkat imbal hasil yang diharapkan yang pada portofolio belum tentu diikuti dengan kinerja portofolio yang baik.

\section{KESIMPULAN}

Berdasarkan hasil analisa data dan pembahasan yang telah dikemukakan maka dapat ditarik kesimpulan. Kesimpulan yang pertama adalahsaham syariah dibutuhkan dalam jumlah cukup banyak pada setiap kondisi perubahan nilai tukar dalam portofolio umum, namun jumlah bobot optimal pada masing saham berfluktuatif jika dibandingkan dengan bobot optimal dalam portofolio syariah. Selain itu, secara total jumlah bobot optimal saham syariah dalam portofolio umum berkurang pada saat kondisi nilai tukar menguat.

Berikutnya, return dan risk dari portofolio syariah lebih tinggi dari pada portofolio umum untuk disetiap kondisi. Hal ini dikarenakan ruang lingkup pemilihan saham potensial pada saat penyusunan portoflio lebih luas daripada ruang lingkup portofolio syariah, sehingga pendistribusian risiko dapat lebih maksimal terjadi. Hal tersebut terbukti dari besarnya jumlah saham pada portofolio umum tersebut dengan diikuti oleh rendahnya risiko dan return yang ada pada portofolio umum. Kinerja portofolio yang diukur dengan metode Sharpe ratio menunjukkan bahwa kinerja portofolio umum memiliki nilai yang lebih tinggi daripada kinerja portofolio syariah untuk disetiap kondisi. Hal tersebut berbanding terbalik dengan tingginya return dan risiko yang ada dalam portofolio syariah.

\section{DAFTAR PUSTAKA}

Alam, N., \& Rajjaque, M., S. (2010). Shariah-compliant equities: empirical evaluation of performance in the european market during credit crunch. Journal of Financial Services Marketing, 15(3). Palgrave Macmillan UK: 228-40. https://doi.org/10.1057/fsm.2010.19.

Albaity, M., \& Ahmad, R. (2011). A comparative analysis of the firm specific deteminants of syariah compliant versus non-syariah compliant firm in Bursa Malaysia. Asian Journal of Business Accounting, 4(1), 59-84.

Ang, R. (1997). Buku pintar pasar modal Indonesia. Jakarta. Mediasoft Indonesia.

Bodie, Z., Kane, A., \& Marcus. (2006). Investasi. Jakarta: Salemba Empat.

Brinson, G. P., Hood, L. R., \& Beebower, G. L. (1986). Determinants of portfolio performance. Financial Analysts Journal, 1, 133-138.

Brinson, G. P., Singer, B. D., \& Beebower, G. L. (1991). Determinants of portfolio performance II: An Update. Financial Analysts Journal, 5, 40-48.

Jurnal Manajemen dan Organisas (JMO),

Vol. 11 No. 2 
Chen, F. Y., \& Lim, Z. T. M. (2015). Diversification: A sharia effect? Some evidence from Malaysia. Procedia-Social and Behavioral Sciences, 216, 193-200.

Chiadmi, M. S., \& Ghaiti, F. (2012). Modeling volatility stock market using the ARCH and GARCH models: comparative study between an islamic and a conventional index (SP Sharia VS SP 500). International Research Journal of Finance and Economics, 91.

Davis, J., Kinniry, F. J., \& Sheay, G. (2007). The asset allocation debate: provocative questions, enduring realities. Valley Forge: Vanguard Investment Counseling \& Research.

Derigs, U., \& Marzban, S. (2009). Review and analysis of current Shariah-compliant equity screening practices. International Journal of Islamic and Middle Eastern, 1(4), 285-303.

Fabbozi FJ. 1999. Manajemen investasi. Jakarta: Salemba Empat.

Gait, A., \& Worthington, A. (2008). An empirical survey of individual consumer, business firmand financial institution attitudes towards Islamic methods of finance. International Journal of Social Economics, 35(1), 783-808.

Girrard, E., \& Hassan, M. K. (2008). Is there a cost to faith-based investing: evidence from FTSE islamic indices. The Journal Investing, 112-121.

Hartono, J. (2010). Teori portofolio dan analisis investasi. Edisi Tujuh. Yogyakarta: BPFE.

Halim, A. (2003). Analisis investasi. Jakarta: Salemba Empat.

Ho, Catherine, S. F., Nurul, A. A. R., Noor, H. M. Y., \& Zaminor, Z. (2014). Performance of global islamic versus conventional share indices: international evidence. Pacific-Basin Finance Journal 28 (June). North-Holland: 110-21. https://doi.org/ 10.1016/J.PACFIN.2013.09.002.

Husnan, S. (2003). Manajemen keuangan teori dan penerapan (keputusan jangka pendek). Edisi 4. Yogyakarta: BPFE.

Husnan, S. (2005). Dasar-dasar teori portofolio dan analisis sekuritas. Edisi 5. Yogyakarta: BPFE.

Husnan, S., \& Pudjiastuti, E. (2006). Dasar-dasar manajemen keuangan. Edisi 5. Yogyakarta: UPP STIM YKPN.

Ibbotson, R., \& Kaplan, P. (2000). Does asset allocation policy explain 40, 90, 100 percent of performance. Financial Analysts Journal, 56(1), 26-33.

Markowitz, H. (1952). Portfolio selection. The Journal of Finance, 7(1), 77-91.

Miguel, Garlappi, L., \& Uppal, R. (2009). Optimal versus naive diversification: how inefficient is the 1/n porfolio strategy?. The Review of Financial Studies, 22(5), 1915-1953.

Mubarok, K. F., Darmawan, A. R., \& Luailiyah, Z. (2017). Optimalisasi portofolio nilai saham: studi komparasi kinerja saham syariah dan non syariah. Jurnal Ekonomi Islam, 8(2), 309 336.

Pepinsky, T. B. (2012). Development, social change and Islamic Finance in contemporary Indonesia. Journal of World Development, 41(12), 157-167.

Shanmugam, B., \& Zahari, R. Z. (2009). A primer on islamic finance. Research Foundation of CFA Institute, (6), 110-121. http://www.tandfonline.com/doi/abs/10.2753/REE1540496X500211.

Sharpe, F. (1995). Risk, market sensitivy and diversification. Financial Analysist Journal, Januari-Februari, 84-88.

Solnik, B. H. (1995). Going global with equities. Financial Analysist Journal, 53(4), 95-96.

Wahyuni, S. (2013). Perbandingan optimisasi portofolio metode mean-variance dengan metode mean-semivariance. Yogyakarta: Unversitas Gajah Mada. 